\title{
Investigate the Role of Education for Increasing Citizens' Awareness in the Implementation and Operation of Wastewater Collection System
}

\author{
Zohreh Mohammadi1, Akramolmolook Lahijanian1*, Abdolah Rashidi Mehrabadi² \\ ${ }^{1}$ Department of Environment \& Energy, Islamic Azad University, Science and Research Branch, Tehran, Iran \\ ${ }^{2}$ Department of Water and Wastewater, Power \& Water University of Technology (PWUT), Tehran, Iran \\ Email: Zmohammadi1974@gmail.com, *lahijanian@srbiau.ac.ir, a_rashidi@pwut.ac.ir
}

How to cite this paper: Mohammadi, Z., Lahijanian, A. and Mehrabadi, A.R. (2017) Investigate the Role of Education for Increasing Citizens' Awareness in the Implementation and Operation of Wastewater Collection System. Open Access Library Journal, 4: e3961

https://doi.org/10.4236/oalib.1103961

Received: September 22, 2017

Accepted: October 23, 2017

Published: October 26, 2017

Copyright $\odot 2017$ by authors and Open Access Library Inc.

This work is licensed under the Creative Commons Attribution International License (CC BY 4.0).

http://creativecommons.org/licenses/by/4.0/

\begin{abstract}
This study aimed to investigate the role of education in promoting citizens' awareness about the issue of wastewater network and facilities in order to reduce the technical, economic, social and environmental problems. This is a descriptive-survey research. Questionnaire was used to collect data. Citizens of district 1 of Water and Wastewater of Mashhad were population of this research including 384 people. SPSS 18 was used to analyze data both descriptive and inferential statistics. Kolmogorov-Smirnov test was used for testing normality of the data. One-sample $t$-test, chi-square test and Spearman rank correlation test, were used to test hypotheses of research. Both of hypotheses of research were confirmed. Hypotheses are effective including raising awareness of citizens in the implementation and proper operation of wastewater network. The results show there is a direct relationship between knowledge level and education level. Due to management, economic, cultural problems, lack of trust and lack of citizen satisfaction, as well as their low level of awareness, implementation and operation of the facility are faced with a problem. According to the results, developing an educational program for citizens and its implementation by public relations and public education by water and Wastewater Company seems essential.
\end{abstract}

\section{Subject Areas}

Environmental Sciences

\section{Keywords}

Wastewater, Citizenship, Education, Operational, Collection System

\section{Introduction}

Today, along with the increasing importance of water in the world, paying atten- 
tion to related and influential industry in ensuring the health and safety of people and the environment has been very important [1]. Water harvesting and delivering it to the consumer, apart from the shortcomings and limitations of the World Wide Web, however, is done. But neglecting the destructive effects of its wastewater is the issue that has been neglected in some societies. While in advanced Western societies with a proper understanding of the necessity of a vital network of wastewater, serious steps have been taken many years ago while in Iran are facing with a delay in this field in recent several decades [2]. Achieving sustainable development and realization of creating healthy city, observing environmental hygiene practices, controlling environmental pollution, specifically in the field of water and wastewater, and avoiding polluting water resources are important factors to provide public health [3].

Urban wastewater collection system generally are made in order to collect and improve the quality of collected wastewater from urban population centers and sometimes some industries' wastewater mixing with municipal wastewater [4].

Due to technical issues, economic and environmental aspects, wastewater facilities of cities require maintenance and protection [5] such as water and gas distribution networks. The importance of proper operation of the wastewater facilities is in its planning and implementation. It results in increasing efficiency, longer life and reduces public facilities during the period of its operation [6]. As well, lack of accurate operation of these facilities resulted in urban environmental pollution resulted in prevalence of different diseases [7]. The water and wastewater company of Mashhad M (a religious city and one of the metropolises of Iran) has been designing, implementing and exploiting the sewage network of the city for many years to protect the environment, reducing the health problems caused by wastewater disposal along the road, control and prevention of infiltration and contamination caused by the disposal of raw sewage to aquifers and the reuse of effluent from wastewater treatment plants. At present, part of the city's sewage network has been implemented and exploited. Part of the city still does not run this project and waste disposal is traditionally done. In the other part, the sewage network is under construction and construction.

Citizens as an important social factor and the user of drinking water providing services supply and wastewater disposal play important role in water and wastewater plans development projects [8]. Problem and significance of this investigation is due to attitude of citizens about wastewater network. Hence, according to importance of this subject, assessing the attitudes and awareness level of citizens as an affecting variable in the implementation and proper operation of the wastewater network and its related installations, the role of education as a factor affecting the promotion of knowledge level and attitudes of citizens in this matter is investigated.

\section{Methodology}

This is a descriptive-survey research. In this research, method and information 
gathering tool in addition to library method, Internet search and archived reports of water and wastewater company of Mashhad, the field method of the citizens' specific questionnaire and interviews of managers and executives and sewage companies in the water and wastewater company of Mashhad has been used.

The hypotheses include raising awareness level of citizens in the effective implementation and utilization of wastewater network. Customer satisfaction is effective over the implementation of water and sanitation development projects. Population of this research includes citizens of water and wastewater company of Mashhad as 384 people by simple random method. Formal validity was used in order to validate the validity of the questionnaire. Thus the questionnaire was distributed among managers and experts of Mashhad Water and wastewater Company. Validity of the questionnaire was assessed by their views. SPSS was used for descriptive and inferential analysis. Kolmogorov-Smirnov test was used to test normality of data. One-sample $t$-test, chi-square test and Spearman rank correlation test were used to test the hypotheses. Viewpoints of 10 managers, experts of water and wastewater company of Mashhad were used to confirm validity of the questionnaire. For calculating reliability of the questionnaire SPSS 18 with Cronbach's alpha was used. The trust factor was calculated for 30 people with Cronbach's alpha which results in Table 1, as below.

According to the Table 1, Cronbach alpha reliability coefficient for the questionnaire is equal to 0.715 (at least Cronbach's alpha) that is higher than $7 \%$ (minimum amount of Cronbach's alpha). Hence, reliability and validity of the questionnaire is good.

\section{Discussion and Results}

Before examining hypotheses of research, in order to learn how to answer questions, the questionnaire was studied by tables and frequency charts. Statistical data describing the results of the questionnaires based on respondents' demographic characteristics including age, sex, education, occupation, etc. are as follows:

- Age of most of respondents (38.5 percent) is between 25 and 35 years.

- Most of respondents (54.4 percent) are male.

- Education level of most of respondents (33.9 percent) is bachelor.

- Most of respondents (34.4 percent) are employees.

According to the Figure 1 and the Table 2, based on citizens' response to the questionnaire to the familiarity level of most of respondents with wastewater network and its facilities is $37.2 \%$. In addition, $18.2 \%$ of the respondents are not familiar with wastewater network and its facilities familiarity level of $37.2 \%$ of respondents is low, $3.6 \%$ is high, $3.4 \%$ is very much.

Table 1. Calculation of reliability (Cronbach's alpha).

\begin{tabular}{c}
\hline Cronbach's alpha coefficient \\
\hline 0.715 \\
\hline
\end{tabular}




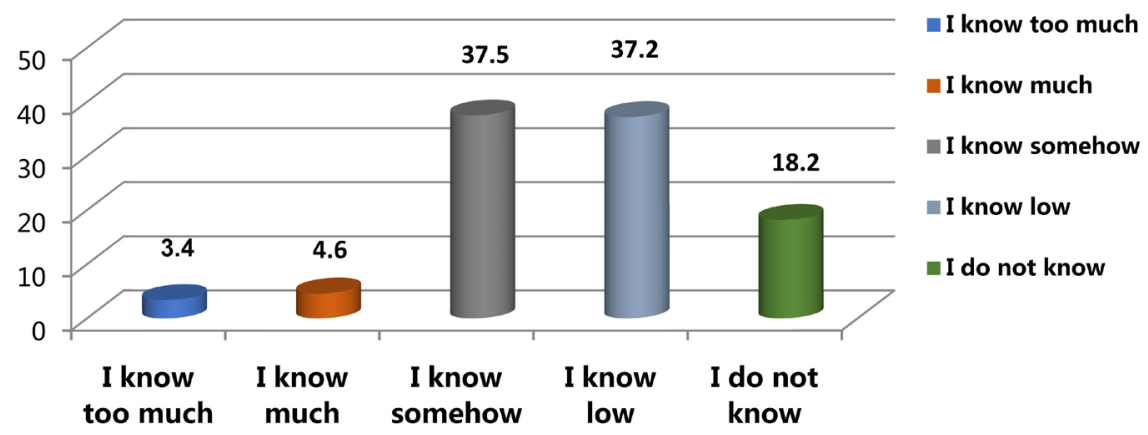

Figure 1. Familiarity level of respondents with Wastewater network of Mashhad.

Table 2. Familiarity level of most of respondents with wastewater collection and its facilities.

\begin{tabular}{ccc}
\hline Familiarity level & Frequency & Percentage \\
\hline I know too much & 13 & 3.4 \\
I know much & 14 & 4.6 \\
I know somehow & 144 & 37.5 \\
I know low & 143 & 37.2 \\
I do not know & 70 & 18.2 \\
Total & 384 & 100 \\
\hline
\end{tabular}

According to the Figure 2 and the Table 3, the importance level of most respondents for the implementation of the wastewater collection system, is medium (56 percent). Also, importance level for $10.6 \%$ of respondents is very much, for $27.9 \%$ is much, for $3.9 \%$ is low, and for $1.6 \%$ is very low.

According to Figure 3 and Table 4, familiarity level of most respondents with public relation services and public education of water and wastewater company is low (38.3). In addition, 37.5\% of respondents are not familiar with public relation services and public education of water and wastewater Company of Mashhad. Familiarity level of $23.2 \%$ of respondents is high somehow. Notably, familiarity level of none of respondents is not very much.

According to Figure 4 and Table 5, most of respondents are not familiar with information system 122 of water and Wastewater Company of Mashhad at all (41.7\%). Around $31 \%$ of respondents are familiar with the information system 122 of Water and wastewater Company low, $23.7 \%$ are familiar with the information system 122 of Water and wastewater Company somehow, $2.3 \%$ are familiar with the information system 122 of Water and wastewater Company very much, $1.3 \%$ are familiar with the information system 122 of Water and wastewater Company very much.

According to Table 6 and Figure 5, most of respondents are not familiar with operating management of their residential area at all (40.1\%). Familiarity level of $38.3 \%$ of respondents is low, $19.5 \%$ of respondents are somehow, $1.8 \%$ of respondents are high, and $0.3 \%$ of respondents are very much. 
56



Very much

Much

Average

- Low

Very low

Figure 2. The importance level of implementation of wastewater collection system.

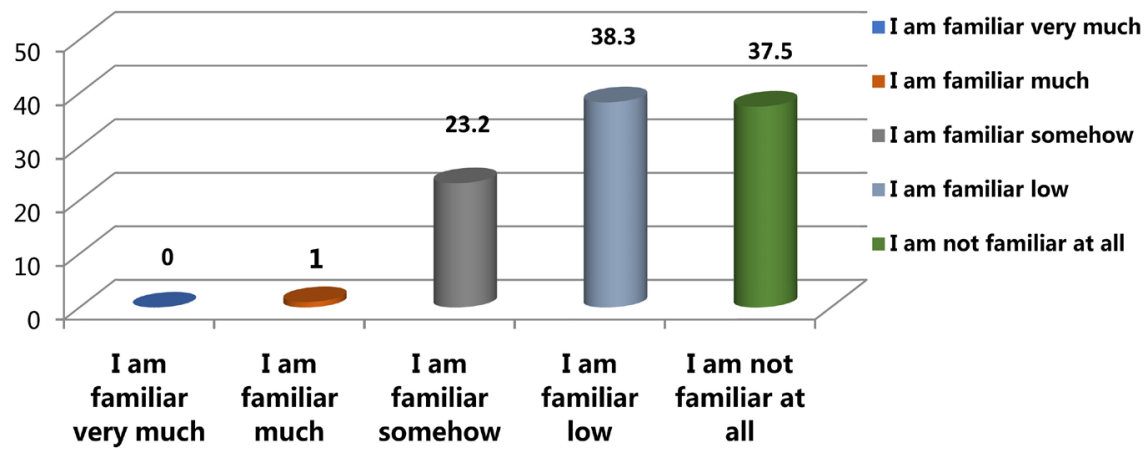

Figure 3. Familiarity level with public services and public education of water and wastewater company.



Figure 4. Familiarity level with the information system 122 of water and wastewater company.

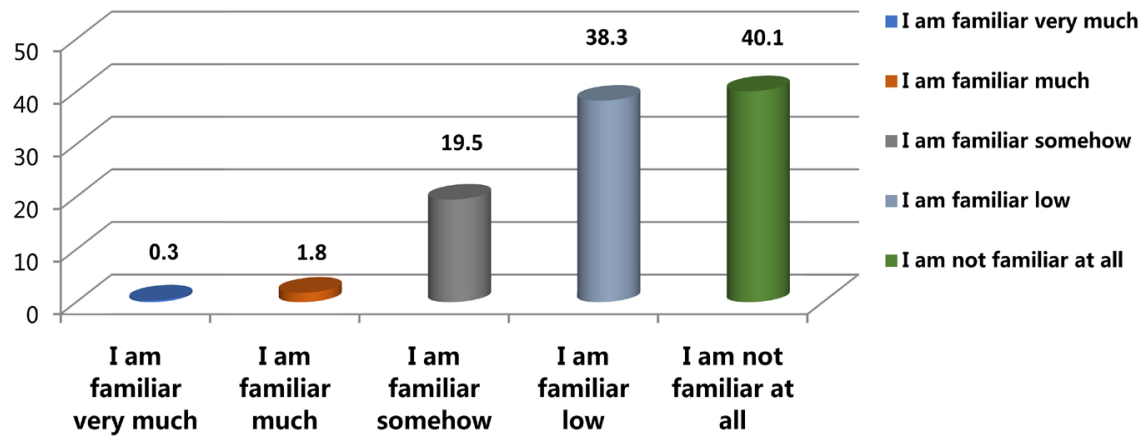

Figure 5. Familiarity level of the operational management of their residential area. 
Table 3. The importance level of wastewater collection system in view of respondents.

\begin{tabular}{ccc}
\hline Importance level & Frequency & Percentage \\
\hline Very much & 215 & 10.6 \\
Much & 107 & 27.9 \\
Average & 41 & 56 \\
Low & 15 & 3.9 \\
Very low & 6 & 1.6 \\
Total & 384 & 100 \\
\hline
\end{tabular}

Table 4. Familiarity of most respondents with public services and public education of Water and wastewater company in view of respondents.

\begin{tabular}{ccc}
\hline $\begin{array}{c}\text { Familiarity level with public relationship services and } \\
\text { public education of water and wastewater services }\end{array}$ & Frequency & Percentage \\
\hline I am familiar very much & 0 & 0 \\
I am familiar much & 4 & 1 \\
I am familiar somehow & 89 & 23.2 \\
I am familiar low & 147 & 38.3 \\
I am not familiar at all & 144 & 37.5 \\
Total & 384 & 100 \\
\hline
\end{tabular}

Table 5. Familiarity level of citizens with information system 122 of water and Wastewater Company in view of respondents.

\begin{tabular}{ccc}
\hline $\begin{array}{c}\text { Familiarity level with information } \\
\text { system 122 of water and Wastewater Company }\end{array}$ & Frequency & Percentage \\
\hline I am familiar very much & 5 & 1.3 \\
I am familiar much & 9 & 2.3 \\
I am familiar somehow & 91 & 23.7 \\
I am familiar low & 119 & 31 \\
I am not familiar at all & 160 & 41.7 \\
Total & 384 & 100 \\
\hline
\end{tabular}

Table 6. Familiarity level of citizens with operating management of life place in view of respondents.

\begin{tabular}{ccc}
\hline Familiarity level with operating management of life place & Frequency & Percentage \\
\hline I am familiar very much & 1 & 0.3 \\
I am familiar much & 7 & 1.8 \\
I am familiar somehow & 75 & 19.5 \\
I am familiar low & 147 & 38.3 \\
I am not familiar at all & 154 & 40.1 \\
Total & 384 & 100 \\
\hline
\end{tabular}


According to Figure 6 and Table 7, most of respondents have not referred to operating management of their life region (49.7\%). Refer level of $24 \%$ of respondents is low, refer level of $20.8 \%$ of respondents is somehow, refer level of $82.5 \%$ of respondents is much, refer level of $3 \%$ of respondents is very much.

According to Table 8 and Figure 7, most of respondents believe that the effect level of education on raising awareness of citizens on the implementation and proper operation of the wastewater network is very much (49.5\%). In addition, $28.4 \%$ of respondents believe this impact level is very much, $14.6 \%$ is in average level, $6.8 \%$ is very much. In addition, $0.8 \%$ of respondents believe that education has no impact on raising awareness level of citizens on proper operating and implementation of wastewater network.

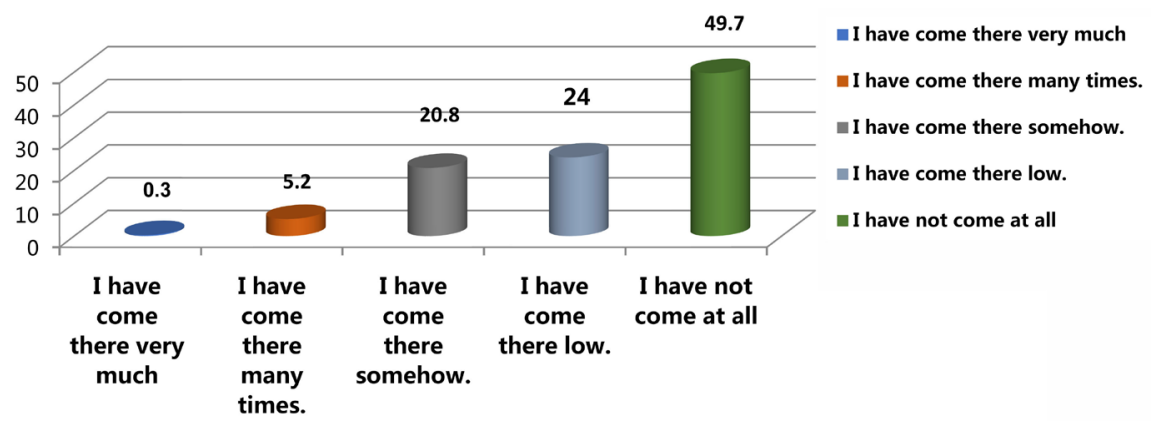

Figure 6. Refer level to operating management of wastewater.

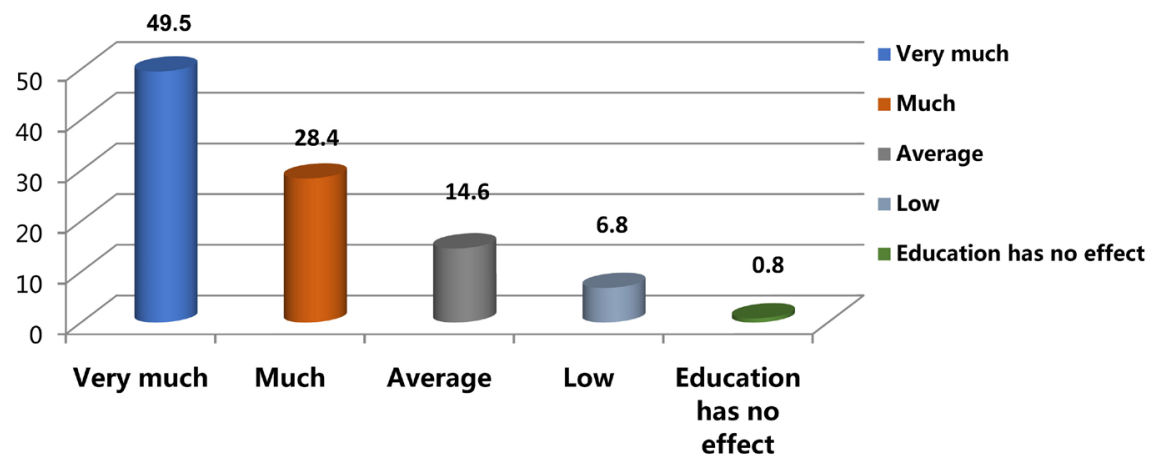

Figure 7. Effect of Education on promoting awareness of the citizens on the implementation and proper operation of the wastewater network.

Table 7. Referring amount of citizens to operation management of residence region in viewpoint of respondents.

\begin{tabular}{ccc}
\hline Coming percentage to operation management of residence region & Frequency & Percentage \\
\hline I have come there very much & 1 & 0.3 \\
I have come there many times & 20 & 5.2 \\
I have come there somehow & 80 & 20.8 \\
I have come there low & 92 & 24 \\
I have not come at all & 191 & 49.7 \\
Total & 384 & 100 \\
\hline
\end{tabular}


Table 8. Impact of education on raising awareness level of citizens in proper implementing and operating of wastewater collection system in viewpoint of respondents.

\begin{tabular}{ccc}
\hline The effect of education on raising awareness of citizens & Frequency & Percentage \\
\hline Very much & 190 & 49.5 \\
Much & 109 & 28.4 \\
Average & 56 & 14.6 \\
Low & 26 & 6.8 \\
Education has no effect & 3 & 0.8 \\
Total & 384 & 100 \\
\hline
\end{tabular}

According to Figure 8 and Table 9, satisfaction level of most of respondents of performance of water and wastewater company in providing services is average (43.6\%). Satisfaction level of $32.9 \%$ of respondents is low, satisfaction level of $6 \%$ is high, satisfaction level of $1 \%$ is very much. In addition, $16.7 \%$ of respondents are not satisfied with performance of wastewater company in providing services at all. The Table 10 shows comparison between descriptive results of questions of questionnaire based on priority level and importance level in viewpoint of citizens.

After describing the questionnaire data, hypotheses were tested and data were analyzed in two descriptive and inferential statistics. In order to describe the above-mentioned data, bar graphs, frequency tables and statistical indicators were used such as frequency, percentage, average. Inferential statistics was used including Kolmogorov-Smirnov test for normality of the data and one-sample $t$-test, chi-square test and Spearman rank correlation test were used to test the hypothesis.

First hypothesis: promote citizens' awareness level in effective implementation and proper operation of the wastewater network.

Single-sample $t$-test was used to investigate the relationship between two variables including "raise the level of awareness of citizens" and "implementation and proper operation of sewerage network".

According to the Table 11, we see that average responses of citizens to the effects of promoting citizens' awareness level in implementing and proper operation of sewerage network is 4.44 that is larger than average mean $\mu=3$. Sig is 0 that is smaller than 0.05. $T$-value is 12.55 that is a positive amount. Hence, $H_{0}$ is rejected with $95 \%$ confidence. According to significant relationship between the two variables, it is claimed that raising awareness of citizens in the implementation and utilization of sewerage network is effective and h1 is confirmed.

The second hypothesis: customer satisfaction over the implementation of water and wastewater projects is effective.

Single-sample $t$-test was used in order to investigate relationship between "customer satisfaction" and "implementation of water and wastewater projects". 
Table 9. Citizen's satisfaction with the performance of water and wastewater services in terms of respondents.

\begin{tabular}{|c|c|c|}
\hline Satisfaction with the performance of water and wastewater company in the provision of services & Frequency & Percentage \\
\hline Very much & 4 & 1 \\
\hline Much & 23 & 66 \\
\hline Average & 167 & 43.5 \\
\hline Low & 126 & 32.8 \\
\hline Not at all & 64 & 16.7 \\
\hline Total & 384 & 100 \\
\hline
\end{tabular}

Table 10. A comparison between descriptive results of questions of questionnaire based on priority level and importance level in viewpoint of citizens.

\begin{tabular}{|c|c|c|c|c|c|c|}
\hline \multirow{2}{*}{ Row } & \multirow{2}{*}{ Subject } & \multicolumn{5}{|c|}{ The importance and priority of the citizens } \\
\hline & & 1 & 2 & 3 & 4 & 5 \\
\hline 1 & $\begin{array}{l}\text { Duty scope of water and } \\
\text { wastewater company }\end{array}$ & $\begin{array}{c}\text { Supply of clean } \\
\text { and sanitation water }\end{array}$ & $\begin{array}{l}\text { Household wastewater } \\
\text { and public collection }\end{array}$ & $\begin{array}{c}\text { Water and } \\
\text { wastewater treatment }\end{array}$ & $\begin{array}{c}\text { Collect } \\
\text { surface runoff }\end{array}$ & $\begin{array}{c}\text { Industrial } \\
\text { wastewater collection }\end{array}$ \\
\hline 2 & $\begin{array}{l}\text { Purpose is using } \\
\text { collection network and } \\
\text { wastewater treatment }\end{array}$ & $\begin{array}{l}\text { Environmental } \\
\text { protection, prevention } \\
\text { of pollution of } \\
\text { groundwater and soil }\end{array}$ & $\begin{array}{c}\text { Collection and } \\
\text { disposal of } \\
\text { wastewater sewage }\end{array}$ & $\begin{array}{c}\text { Promote public } \\
\text { health and prevent } \\
\text { disease outbreaks }\end{array}$ & $\begin{array}{c}\text { Lack of } \\
\text { sanitation in } \\
\text { public places }\end{array}$ & $\begin{array}{l}\text { Wastewater } \\
\text { reuse }\end{array}$ \\
\hline 3 & $\begin{array}{l}\text { Social problems of } \\
\text { establishing } \\
\text { wastewater network } \\
\text { in residential areas }\end{array}$ & Traffic disruptions & $\begin{array}{l}\text { Noise pollution } \\
\text { and discomfort }\end{array}$ & $\begin{array}{l}\text { Endanger the } \\
\text { physical and } \\
\text { mental health of } \\
\text { citizens and workers }\end{array}$ & $\begin{array}{c}\text { Damage to } \\
\text { public and } \\
\text { private property }\end{array}$ & $\begin{array}{c}\text { Revenue } \\
\text { decreased } \\
\text { of shopkeepers }\end{array}$ \\
\hline 4 & $\begin{array}{l}\text { The major problems } \\
\text { in the operation of } \\
\text { the sewerage network }\end{array}$ & $\begin{array}{l}\text { Increasing the } \\
\text { beetles and insects }\end{array}$ & Scent at home & $\begin{array}{l}\text { Back home sewage } \\
\text { problem (rejection) }\end{array}$ & Clogging pipes & No problem \\
\hline 5 & $\begin{array}{l}\text { Effect of implementing } \\
\text { sewerage network } \\
\text { in the lives of citizens }\end{array}$ & $\begin{array}{l}\text { Maintaining Health } \\
\text { And health of citizens }\end{array}$ & $\begin{array}{l}\text { Environmental } \\
\text { Protection }\end{array}$ & $\begin{array}{c}\text { Providing social } \\
\text { welfare of citizens }\end{array}$ & $\begin{array}{c}\text { providing } \\
\text { economic } \\
\text { welfare of citizens }\end{array}$ & No effect \\
\hline 6 & $\begin{array}{l}\text { Benefits of buying } \\
\text { drainage split }\end{array}$ & $\begin{array}{l}\text { Environmental } \\
\text { protection and } \\
\text { health promotion }\end{array}$ & $\begin{array}{l}\text { Maintain the strength } \\
\text { of the foundations } \\
\text { of buildings }\end{array}$ & $\begin{array}{l}\text { Contribute to the } \\
\text { implementation of } \\
\text { development projects } \\
\text { and infrastructure }\end{array}$ & $\begin{array}{c}\text { Economic } \\
\text { advantage than } \\
\text { absorption wells }\end{array}$ & $\begin{array}{l}\text { There is } \\
\text { no advantage }\end{array}$ \\
\hline 7 & $\begin{array}{l}\text { The reasons } \\
\text { for wanting } \\
\text { to buy a wastewater split }\end{array}$ & Lack of knowledge & $\begin{array}{l}\text { High costs of split } \\
\text { wastewater buy }\end{array}$ & $\begin{array}{l}\text { Fear of further } \\
\text { problems such as } \\
\text { odor and rejection } \\
\text { of waste production }\end{array}$ & $\begin{array}{l}\text { Accountability } \\
\text { of current system } \\
\text { i.e. cesspools }\end{array}$ & $\begin{array}{l}\text { The need to } \\
\text { reform home } \\
\text { plumbing system }\end{array}$ \\
\hline 8 & $\begin{array}{c}\text { Priority of } \\
\text { purchase type of } \\
\text { wastewater split }\end{array}$ & By installments & $\begin{array}{l}\text { Using banking } \\
\text { facilities }\end{array}$ & $\begin{array}{l}\text { Not wanting } \\
\text { to Buy Split }\end{array}$ & In cash & $\begin{array}{c}\text { Not wanting to } \\
\text { buy a split even } \\
\text { when water is stopped }\end{array}$ \\
\hline 9 & $\begin{array}{c}\text { Sewage-borne } \\
\text { diseases to humans }\end{array}$ & Infectious diseases & $\begin{array}{l}\text { Diarrheal } \\
\text { diseases }\end{array}$ & Cholera & Typhoid fever & Hepatitis \\
\hline 10 & $\begin{array}{c}\text { Because of its usefulness } \\
\text { and problems } \\
\text { of absorption wells }\end{array}$ & $\begin{array}{c}\text { Soil and } \\
\text { groundwater } \\
\text { pollution }\end{array}$ & $\begin{array}{l}\text { Limited capacity is } \\
\text { and early discharge }\end{array}$ & $\begin{array}{l}\text { Safety problems } \\
\text { related to } \\
\text { loss of well }\end{array}$ & $\begin{array}{c}\text { Traditional } \\
\text { and old type }\end{array}$ & $\begin{array}{l}\text { The high } \\
\text { cost cavity }\end{array}$ \\
\hline 11 & $\begin{array}{l}\text { The best media to } \\
\text { educate and increase } \\
\text { awareness-raising } \\
\text { in the construction } \\
\text { of sewerage network }\end{array}$ & Radio and TV & $\begin{array}{l}\text { Newspapers } \\
\text { and magazines }\end{array}$ & $\begin{array}{l}\text { Posters, pamphlets } \\
\text { and publications by } \\
\text { the Water and } \\
\text { Wastewater } \\
\text { Company }\end{array}$ & $\begin{array}{l}\text { Education in } \\
\text { schools, raised } \\
\text { by Clergymen } \\
\text { in mosques }\end{array}$ & $\begin{array}{l}\text { Books, } \\
\text { educational } \\
\text { videos }\end{array}$ \\
\hline 12 & $\begin{array}{l}\text { Doing affairs and } \\
\text { receiving services of } \\
\text { utilization management } \\
\text { clients of living area }\end{array}$ & $\begin{array}{l}\text { Solving payment } \\
\text { of Water and } \\
\text { Sewage problems }\end{array}$ & $\begin{array}{l}\text { Separate water meter } \\
\text { of apartment and } \\
\text { condominium }\end{array}$ & $\begin{array}{l}\text { Sign up and receive } \\
\text { wastewater split }\end{array}$ & $\begin{array}{l}\text { Sign up and } \\
\text { receive the } \\
\text { water branching }\end{array}$ & $\begin{array}{l}\text { Recoil sewage } \\
\text { into building and } \\
\text { Beetle Infestation } \\
\text { problem solving }\end{array}$ \\
\hline
\end{tabular}


Table 11. One-sample $t$-test results (first hypothesis).

\begin{tabular}{|c|c|c|c|c|c|c|c|c|}
\hline \multirow[t]{2}{*}{ Variable } & \multirow[t]{2}{*}{ Number } & \multirow[t]{2}{*}{ Mean } & \multirow[t]{2}{*}{$\begin{array}{l}\text { Standard } \\
\text { deviation }\end{array}$} & \multirow[t]{2}{*}{$t$-test } & \multirow{2}{*}{$\begin{array}{c}\text { The average } \\
\text { difference } \\
\text { between } \\
\text { the assumed mean }\end{array}$} & \multirow[t]{2}{*}{ Sig } & \multicolumn{2}{|c|}{$\begin{array}{l}\text { The average } \\
\text { difference of the } \\
\text { assumed mean }\end{array}$} \\
\hline & & & & & & & Max limit & Min limit \\
\hline $\begin{array}{l}\text { Responses of citizens to the effect } \\
\text { level of promoting awareness }\end{array}$ & & & & & & & & \\
\hline $\begin{array}{l}\text { of the citizens in the } \\
\text { implementation and proper } \\
\text { operation of sewerage network }\end{array}$ & 384 & 4.44 & 2.25 & 12.55 & 1.44 & 0.00 & 1.21 & 1.66 \\
\hline
\end{tabular}

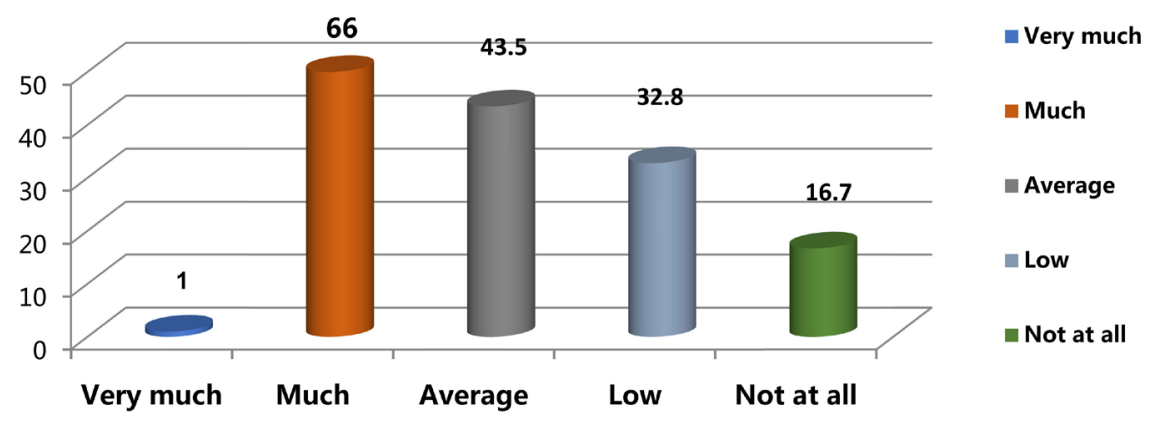

Figure 8. Satisfaction level of citizens of performance of water and wastewater company in providing services.

According to the Table 12, it is observed that the average of customer satisfaction on implementation of development projects of Water and Wastewater Company is 57.3 that is larger than the average assumptions $(\mu=3)$. Sig is 0 that is less than 0.05 . Also, $t$-value is 12.97 that is a positive amount. Hence, $H_{0}$ is rejected with $95 \%$ confidence. According to significant relationship between the two variables, it is said satisfaction level of clients on implementation of clients is effective on water and sanitation development projects.

According to Table 13, Spearman's rank correlation coefficient value between awareness of people and education level is 0.237 . As sig are 0 , which is less than 0.05 . Hence, it is claimed there is a significant relationship between awareness of people and their education level. As the correlation coefficient is positive, it is a positive and direct relationship i.e. more educational level of people results in higher awareness of sewerage network and its related installations.

According to Table 14, Spearman's rank correlation coefficient value is 0.266 that is larger than 0.05 . Hence, $H_{0}$ is accepted by $95 \%$ confidence. So, there is not significant relationship between awareness of people and their age.

Based on the Table 15, the amount of Spearman's rank correlation coefficient between the awareness of the people and their job is 0.122 . As sig level is 0.017 and is less than 0.05 , hence there is a significant level is 0.017 , that is less than 0.05 , there is a significant relationship between awareness of people and their job. As correlation amount is positive, the relationship is positive and direct i.e. due to higher people's educational level in society, their awareness of Sewerage network and its related installations would be more. 
Table 12. Results of one-sample $t$-test (second hypothesis).

\begin{tabular}{|c|c|c|c|c|c|c|c|c|}
\hline \multirow[t]{2}{*}{ Variable } & \multirow[t]{2}{*}{ Number } & \multirow[t]{2}{*}{ Average } & \multirow[t]{2}{*}{ SD } & \multirow[t]{2}{*}{$T$-Value } & \multirow{2}{*}{$\begin{array}{l}\text { The average } \\
\text { difference between } \\
\text { the assumed mean }\end{array}$} & \multirow[t]{2}{*}{ Sig } & \multicolumn{2}{|c|}{$\begin{array}{l}\text { The average difference } \\
\text { of the assumed mean }\end{array}$} \\
\hline & & & & & & & Max limit & Min limit \\
\hline $\begin{array}{l}\text { Responses of citizens to the impact } \\
\text { of customer satisfaction on water and } \\
\text { sanitation development projects }\end{array}$ & 384 & 3.57 & 0.87 & 12.97 & 0.57 & 0.00 & 0.48 & 0.66 \\
\hline
\end{tabular}

Table 13. Spearman rank correlation test results between the public awareness and education level.

\begin{tabular}{cccc}
\hline Awareness & education level & Number \\
level of people & Correlation & Sig & 384 \\
\hline
\end{tabular}

Table 14. Spearman rank correlation test results between knowledge level and age.

\begin{tabular}{|c|c|c|c|}
\hline \multirow{3}{*}{$\begin{array}{c}\text { Awareness } \\
\text { level of people }\end{array}$} & \multicolumn{3}{|c|}{ Age } \\
\hline & Correlation & Sig & Number \\
\hline & $57 \%$ & 0.266 & 384 \\
\hline
\end{tabular}

Table 15. Spearman rank correlation results between the awareness of people and job.

\begin{tabular}{cccc}
\hline Awareness & Job & Number \\
level of people & correlation & Sig & 384 \\
\hline
\end{tabular}

According to Table 16, Chi-Square amount is 29.313. As sig is 0 that is less than 0.05 , there is a significant relationship between people's awareness and their gender. According to Table 17, awareness amount about sewerage network and its related installations among female respondents was very low among $16 \%$, low 0.48 , average in $30.9 \%$, much in $0 \%$, very much $5.1 \%$.

In addition, awareness level about sewerage network and its related installations among male respondents in $20.1 \%$ was very low, in $28.2 \%$ was low, in $43.1 \%$ was average, in $6.7 \%$ was much, in $1.9 \%$ was very much. Generally, average level of awareness about sewerage network and its related installations in men is more than women. Also Figure 9 shows compare the awareness of the sewerage network and its related installations between male and female respondents too.

\section{Conclusions}

Wastewater collection and treatment projects with many advantages, provide accessibility to important goals including protecting the environment, preventing pollution of water resources, development of public health and the reuse of wastewater in various sectors, especially agriculture. It would be possible by comprehensive planning. The implementation of such plans is inevitable due to 




Figure 9. Compare the awareness of the sewerage network and its related installations between male and female respondents.

Table 16. Results of chi-square test (Chi-Square).

\begin{tabular}{cccc}
\hline $\begin{array}{c}\text { Awareness } \\
\text { of people }\end{array}$ & Chi-Square & Gender & \\
& 29.313 & 0.00 & Freedom degree \\
\hline
\end{tabular}

Table 17. Frequency and percentage of people awareness based on gender.

\begin{tabular}{ccccccccc}
\hline \multirow{2}{*}{ Gender } & \multicolumn{6}{c}{ people awareness level } & \multirow{2}{*}{ Total } \\
\cline { 3 - 7 } & & Very low & Low & Average & Much & Very much & \\
\hline \multirow{2}{*}{ Female } & Frequency & 28 & 84 & 54 & 0 & 9 & 175 \\
& Percentage & 0.16 & 0.48 & 30.9 & 0 & 5.1 & 100 \\
\multirow{2}{*}{ Male } & Frequency & 42 & 59 & 90 & 14 & 4 & 209 \\
& Percentage & 20.1 & 28.2 & 43.1 & 6.7 & 1.9 & 100 \\
\hline
\end{tabular}

psychological impacts and human and society health [9]. In some cases, drainage projects have been implemented without real needs assessments and studies, with high costs. But in practice, good performance is not achieved and installations are gone out of benefit before expiration of benefit life. In some cities due to the lack of a coordinated approach, there is an unbalanced growth in different sectors of sewage plans such as networks implement and construction of sewage treatment plant under assumption attracting clients of wastewater [10].

According to the results, lack of public welcome of wastewater plan due to management problems, social costs, economic costs, cultural costs, lack of informing, lack of satisfaction and trust of citizens of performance of wastewater and water companies, low level of awareness, their familiarity and awareness about wastewater facilities are important points that provide problems in realization of the goals.

It seems reversal in policy, a review of existing practices in wastewater projects of technical feasibility in terms of economic, social and environmental aspects, as well as implement of methods to increase citizen participation as an impor- 
tant social factor and user of drinking water supply services by water companies by increasing their awareness level of water and wastewater facilities and advantages of implementing wastewater facilities plans and decreasing environmental consequences plays important role in water and sanitation development projects [11]. Training and notifying residents of the city can be effective in the way of creating proper attitudes, thoughts and behaviors [12].

Citizens as recipients of water and wastewater services are required to increase their awareness of the benefits of implementing sewage projects and reducing environmental impacts through education, in addition to attracting them into participating in the proper implementation and operation of sewage installations. Therefore, it is necessary to adjust the education provided to citizens along with process, structure and integrated program. The hope is that with a scientific look at and fundamental view to the Water and Wastewater Company Mashhad, the field of realization of this wish is provided. Planning for citizenship teaching in order to move from the status quo to the optimal situation requires the gradual formulation and implementation and evaluation of programs in correct and scientific way.

As all of people acknowledged, cultural development and changing require time and patience. It is essential to apply citizenship training resources for their participation and social mobility of citizens. In this way, it is necessary to use some methods with social acceptance with positive changes adaptable with social cultural environmental criterion. The process of developing a special education program for citizens includes: identifying educational needs, setting educational goals, organizing educational content, selecting techniques and methods of training, identifying required educational resources, preparing lesson plans, preparing tests and methods for measuring the amount of Learn learners, run and administer education and assessment of educational program.

\section{References}

[1] Jani Far, H. (2003) A Study on Monitoring and Measuring Program of Customer Satisfaction of Ahvaz Water and Wastewater Company. MA Thesis, Educational Management, Islamic Azad University, Ahvaz, 5.

[2] Mostofi, S. and Bakhtiyari, H. (2006) Problems of Wastewater Projects in Iran. The First National Conference of Operation on Water and Sanitation Sector, Feb 21-23 2006, Tehran, Iran, 124-127.

[3] Leyli, M. (2010) Municipal Wastewater Management in Developing Countries: Principles and Engineering. Andisheh Rafi, Tehran, 42-44.

[4] Mousavi, G.H. (2011) Wastewater Collection Methods. Hafiz Publication, Tehran, 21 p.

[5] Bedelians Gholi Kandi, G., et al. (2007) Introduction to the Municipal Sewer Network Administrator. Center for Research and Improve the Efficiency of Water and Wastewater Industry, the Department of Energy, $78 \mathrm{p}$.

[6] Mahmoodi, S. (2006) Operation Management of Water and Wastewater in the Country. The first National Conference of Operation on Water and Sanitation Sector, Feb 21-23 2006, Tehran, Iran, 143-146. 
[7] Riyahi Khoram, M. (2005) New Steps in a Fundamental Review of Master Plans for Urban Sewage. Daneshjoo Publications, Hamedan, 46 p.

[8] Beygi, F., et al. (2008) Private Sector Participation in the Operation of Water and Wastewater Facilities, Why and How? The Fourth Meeting of the Directors of Water and Wastewater, Oct 17-19 2008, Tehran, Iran, 76-78.

[9] Singh, R. (2012) Urban Infrastructure Development \& Financial Allocation for the Various Urban Development Programms \& Schemes in Haryana. IOSR Journal of Humanities \& Social Science, 4, 31-35.

[10] ABFA (2012) Regulations of Recognize the Competence of the Operation Companies and Maintenance of Wastewater Treatment. Department of Water Affairs and ABFA, Operation System Office ABFA, 56 p.

[11] Babakhani, M., et al. (2008) Methods for Calculating the Social Cost of Implementation and Reconstruction of Sewer Network. The Second Conference of Water and Wastewater with Operation Approach, Oct 8-9 2008, Tehran, Iran, 18-19.

[12] Karimi, D. (2008) Environmental Education and Citizenship Behavior. 9th Edition, Environmental Management Press, Municipality of Tehran, $22 \mathrm{p}$.

Submit or recommend next manuscript to OALib Journal and we will provide best service for you:

- Publication frequency: Monthly

- 9 subject areas of science, technology and medicine

- Fair and rigorous peer-review system

- Fast publication process

- Article promotion in various social networking sites (LinkedIn, Facebook, Twitter, etc.)

- Maximum dissemination of your research work

Submit Your Paper Online: Click Here to Submit

Or Contact service@oalib.com 